\title{
STRATEGI ALOKASI BELANJA PEMERINTAH DAERAH UNTUK MENINGKATKAN INDEKS PENDIDIKAN DI PROVINSI BANTEN
}

\author{
Local Government Expenditure Allocation Strategies to Increase Education Index in \\ Banten Province
}

\author{
Abdullah Al Mizan' ${ }^{1}$ A. Faroby Falatehan ${ }^{2}$, Ekawati Sri Wahyuni ${ }^{3}$ \\ ${ }^{1}$ Staf Kantor Pelayanan Perbendaharaan Negara Serang. Email: mizan300384@gmail.com \\ 2Pengajar Departemen Ekonomi Sumberdaya dan Lingkungan. Fakultas Ekonomi dan Manajemen. IPB. \\ Email: robiefa@gmail.com \\ 3Pengajar Departemen Sains Komunikasi dan Pengembangan Masyarakat, Fakultas Ekologi Manusia. IPB \\ Email: ekawatiwahyuni@gmail.com
}

\begin{abstract}
Human development measured by Human Development Index (HDI) is composed of three components: health index, education index, and expenditure index. HDI Banten on year 2016 was ranked 8th in Indonesia, but the education index has the lowest value among the other components. Whereas education is a capital which is very important for people to achieve better welfare. This study aimed to formulate strategies to improve education index through education budget allocation in Banten Province. The analytical methods used were descriptive analysis, panel data regression analysis, SWOT analysis, and QSPM. Descriptive analysis was used to give an overview of the education condition in Banten Province. By using fixed effect model panel data regression, found that income per capita, School Enrollment Rate of high schools level, Pupil-Teacher Ratio of high schools level, and Number of high schools had positive and significant influences on education index in Banten Province. Meanwhile, based on the interview results of key respondents, by using SWOT techniques obtained six grand strategies that could improve the education index. The strategies obtained were analyzed using QSPM. The QSPM results showed the priority strategies for increasing the education index was by the policy improvement and increase in the budget allocation in the education sector.
\end{abstract}

Key words: HDI, education index, SWOT, QSPM

\begin{abstract}
ABSTRAK
Pembangunan manusia yang diukur melalui Indeks Pembangunan Manusia (IPM) dibentuk dari tiga komponen yakni indeks kesehatan, indeks pendidikan, dan indeks pengeluaran. IPM Banten Tahun 2016 menduduki peringkat 8 terbesar di Indonesia Namun demikian, indeks pendidikan memiliki nilai yang paling rendah di antara komponen lainnya. Padahal pendidikan merupakan salah satu modal yang sangat penting bagi seseorang untuk menuju kesejahteraan yang lebih baik. Penelitian ini bertujuan untuk merumuskan strategi meningkatkan indeks pendidikan melalui alokasi anggaran pendidikan. di Provinsi Banten Metode analisis yang digunakan yakni analisis deskriptif, analisis regresi data panel, analisis SWOT, dan QSPM. Analisis deskriptif digunakan untuk memberikan gambaran umum pendidikan di Provinsi Banten. Sedangkan dengan menggunakan regresi data panel fixed effect model didapat hasil bahwa pendapatan perkapita, Angka Partisipasi Sekolah (APS) tingkat SMA, Rasio Murid per Guru (RMG) tingkat SMA, dan Jumlah SMA memiliki pengaruh yang positif dan signifikan terhadap indeks pendidikan di Provinsi Banten. Sementara itu berdasarkan hasil wawancara kepada responden kunci, melalui teknik SWOT diperoleh enam strategi yang dapat meningkatkan indeks pendidikan. Strategi yang didapat kemudian dianalisis menggunakan QSPM. Hasil analisis QSPM menunjukkan bahwa strategi prioritas untuk meningkatkan indeks pendidikan yakni melalui penyempurnaan kebijakan dan peningkatan alokasi anggaran di bidang pendidikan.
\end{abstract}

Kata kunci: IPM, Indeks Pendidikan, SWOT, QSPM

\section{PENDAHULUAN}

Pembangunan manusia sebagai ukuran kinerja pembangunan secara keseluruhan dibentuk melalui pendekatan tiga dimensi dasar, yaitu umur panjang dan sehat, pengetahuan, dan penghidupan yang layak. Semua indikator yang merepresentasikan ketiga dimensi ini terangkum dalam satu nilai tunggal, yaitu 
angka Indeks Pembangunan Manusia (IPM). Angka IPM disajikan pada tingkat nasional, provinsi, dan kabupaten/kota oleh Badan Pusat Statistik. Penyajian IPM menurut daerah memungkinkan setiap provinsi dan kabupaten/kota mengetahui peta pembangunan manusia baik pencapaian, posisi, maupun disparitas antar daerah. Melalui peningkatan ketiga indikator tersebut diharapkan akan terjadi peningkatan kualitas hidup manusia. Namun demikian, keberhasilan pembangunan manusia tidak dapat dilepaskan dari kinerja pemerintah yang berperan dalam menciptakan regulasi bagi tercapainya tertib sosial.

Provinsi Banten merupakan provinsi termuda di Pulau Jawa yang juga menjadi gerbang pintu masuk datangnya wisatawan yang dapat menciptakan devisa negara. Selain itu, Banten juga menjadi penyangga Ibukota Negara. Dalam tataran nasional, IPM Banten menduduki peringkat 8 terbesar di Indonesia selama kurun waktu enam tahun terakhir dengan nilai yang semakin meningkat dari tahun ke tahun yang dapat dilihat pada Gambar 1. Pada tahun 2016, Provinsi Banten mampu mencapai Indeks Pembangunan Manusia sebesar 70,96 (BPS 2017) (kategori pembangunan manusia yang tinggi) atau lebih besar dari rata rata IPM nasional yang sebesar 70,18. Capaian ini meningkat dibanding tahun 2015 yang sebesar 70,27 (BPS 2016).

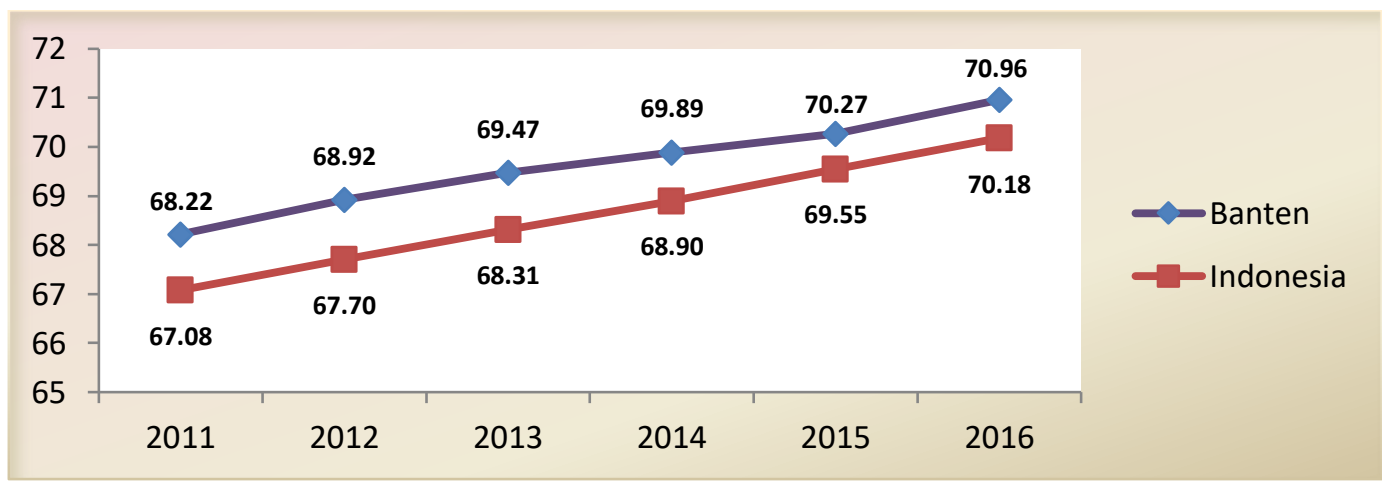

Sumber : Badan Pusat Statistik

Gambar 1. IPM Indonesia dan Provinsi Banten

Lebih lanjut, meskipun IPM di Banten berkategori tinggi, namun masih terlihat adanya kesenjangan pembangunan manusia antar kabupaten/kota yang ditunjukkan dari IPM yang bervariasi dari 62,78 hingga 80,11 pada tahun 2016. Selain itu, kita juga bisa melihat perbedaan yang mencolok terkait komponen penyusun IPM di masing-masing kabupaten/kota maupun provinsi Banten sendiri dimana indeks pendidikan memiliki nilai yang paling kecil di antara komponen penyusun IPM lainnya, yakni Indeks Kesehatan dan Indeks Pengeluaran yang dapat dilihat pada Tabel 1.

Sebagaimana kita ketahui bahwa pendidikan merupakan salah satu modal yang sangat penting bagi seseorang untuk menuju kesejahteraan yang lebih baik. Pemerintah mempunyai peran besar dalam mencerdaskan kehidupan bangsa sehingga program pendidikan mempunyai andil besar terhadap kemajuan sosial-ekonomi suatu bangsa. 
Tabel 1. Komponen Indeks Pembangunan Manusia (IPM) menurut Kabupaten/Kota di Provinsi Banten, 2016

\begin{tabular}{lcccc}
\hline \multicolumn{1}{c}{ Kabupaten/kota } & $\begin{array}{c}\text { Indeks } \\
\text { Kesehatan }\end{array}$ & $\begin{array}{c}\text { Indeks } \\
\text { Pendidikan }\end{array}$ & $\begin{array}{c}\text { Indeks } \\
\text { Pengeluaran }\end{array}$ & IPM \\
\hline Pandeglang & 0.6734 & 0.5929 & 0.6384 & 63.40 \\
Lebak & 0.7143 & 0.5372 & 0.6447 & 62.78 \\
Tangerang & 0.7595 & 0.6107 & 0.7536 & 70.44 \\
Serang & 0.6740 & 0.5763 & 0.7109 & 65.12 \\
Kota Tangerang & 0.7898 & 0.7152 & 0.8022 & 76.81 \\
Kota Cilegon & 0.7114 & 0.6868 & 0.7653 & 72.04 \\
Kota Serang & 0.7286 & 0.6375 & 0.7734 & 71.09 \\
Kota Tangerang Selatan & 0.8022 & 0.7771 & 0.8247 & 80.11 \\
\hline
\end{tabular}

Sumber : Badan Pusat Statistik

Peranan tersebut dijalankan pemerintah, khususnya oleh pemerintah daerah melalui kebijakan-kebijakan pembangunan dan juga melalui kebijakan fiskal berupa pengelolaan keuangan daerah. Salah satu kebijakan pemerintah daerah yang dipandang mampu meningkatkan indeks pendidikan di daerah adalah belanja pemerintah daerah bidang pendidikan. Secara umum, alokasi belanja pemerintah daerah bidang pendidikan di Provinsi Banten semakin meningkat dari tahun ke tahun. Alokasi dana pendidikan bertujuan untuk membiayai segala aktivitas dan pembangunan di bidang pendidikan. Dengan meningkatnya anggaran bidang pendidikan diharapkan terjadi peningkatan kualitas sumber daya manusia di Banten yang salah satu indikatornya yakni peningkatan nilai indeks pendidikan. Data alokasi belanja pemerintah daerah Provinsi Banten disajikan pada Gambar 2.

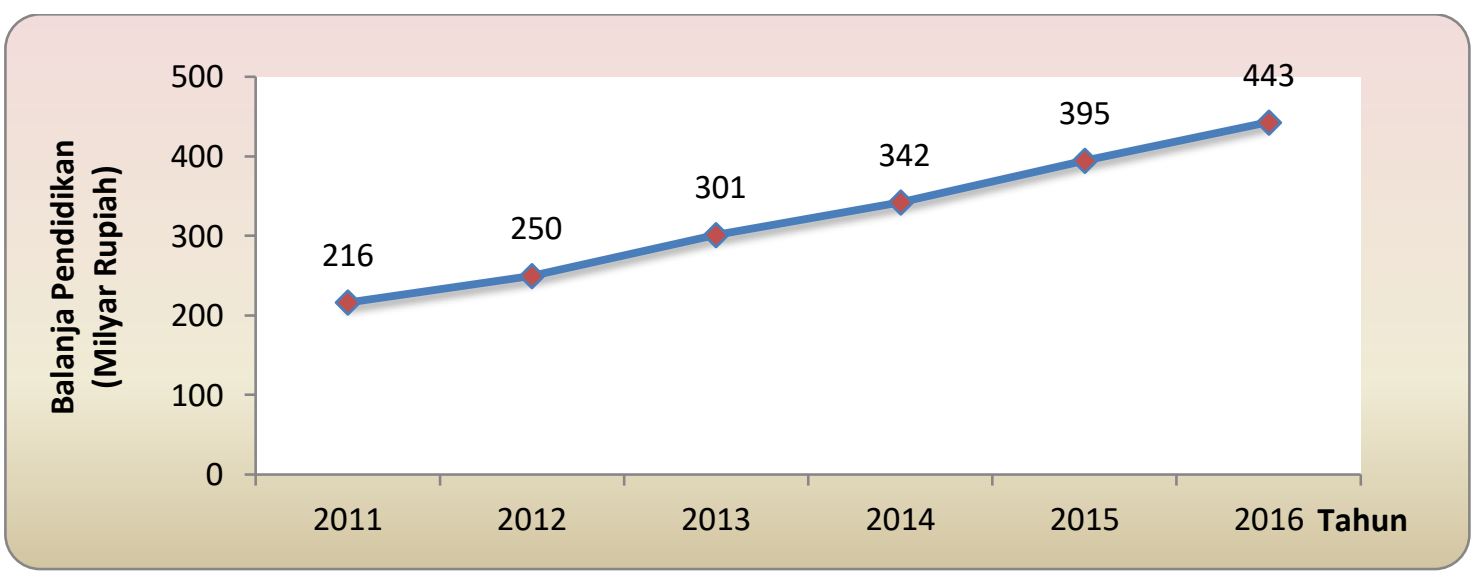

Gambar 2. Alokasi Belanja Pendidikan di Provinsi Banten Tahun 2011 - 2016

Mengacu pada berbagai alasan yang telah disebutkan, maka perlu dilakukan penelitian tentang Strategi Alokasi Belanja Pemerintah Daerah untuk Meningkatkan Indeks Pendidikan di Provinsi Banten. Berdasarkan berbagai permasalahan tersebut, tujuan dari penelitian ini adalah untuk: 1) Mengidentifikasi dan menganalisis kondisi umum pendidikan di Provinsi Banten; 2) Mengidentifikasi faktor-faktor yang berpengaruh terhadap indeks pendidikan di Provinsi Banten; serta 3) Merumuskan strategi atau program untuk meningkatkan indeks pendidikan di Provinsi Banten.

\section{METODE PENELITIAN}

Penelitian dilakukan di Provinsi Banten dengan menggunakan data tahun 2010 hingga tahun 2016. Data sekunder berasal dari Dinas Pendidikan, Badan Pusat Statistik (BPS), Badan Pengelola 
Keuangan dan Aset Daerah (BPKAD), Badan Perencanaan Pembangunan Daerah (Bappeda), Direktorat Jenderal Perimbangan Keuangan (DJPK) Kementerian Keuangan maupun instansi terkait lainnya. Sedangkan data primer diperoleh melalui wawancara dan penyebaran kuesioner terhadap pihak pemerintah daerah yaitu Dinas Pendidikan, BPKAD, dan Bappeda. Waktu pengambilan dan pengolahan data penelitian dilakukan selama lima bulan dimulai pada bulan Februari sampai dengan bulan Juni 2017 pada instansi yang terkait.

Analisis yang digunakan sesuai dengan urutan tujuan dalam penelitian ini adalah: (1) Analisis deskriptif untuk menggambarkan kondisi pendidikan secara umum; (2) Analisis regresi berganda menggunakan data panel untuk mengidentifikasi faktor-faktor yang mempengaruhi indeks pendidikan di Banten; serta (3) Analisis SWOT sebagai dasar dan perumusan strategi dalam usaha peningkatan pendidikan serta Quantitative Strategic Planning Matriks (QSPM) untuk menyusun daftar prioritas strategi.

Menurut Ariefianto (2012), data dengan karakteristik panel adalah data yang berstruktur urut waktu sekaligus cross section. Pada penelitian ini digunakan empat variabel yang diduga berpengaruh terhadap indeks pendidikan yakni pendapatan (PDRB) per kapita, APS tingkat SMA, Jumlah SMA, dan Rasio Murid per Guru SMA. SMA yang dimaksud termasuk yang sederajat, yakni SMK dan MA. Data yang digunakan adalah data dalam kurun waktu 7 tahun terakhir yaitu 2010-2016. Adapun model regresi data panel dalam penelitian ini adalah:

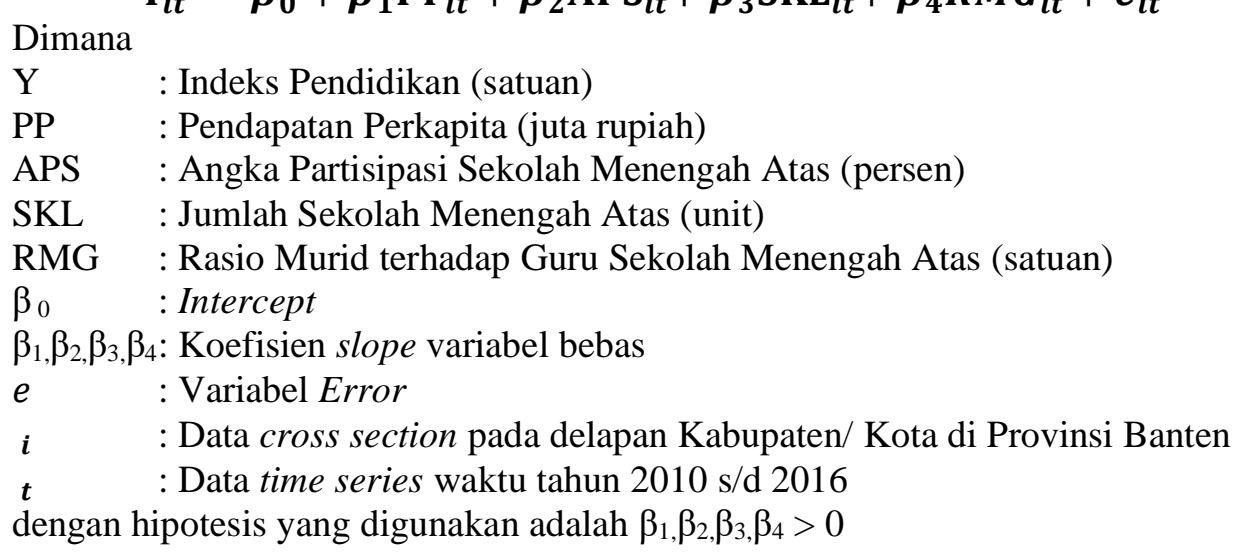$$
\text { Y : Indeks Pendidikan (satuan) }
$$$$
\text { PP : Pendapatan Perkapita (juta rupiah) }
$$$$
\text { APS : Angka Partisipasi Sekolah Menengah Atas (persen) }
$$$$
\text { SKL : Jumlah Sekolah Menengah Atas (unit) }
$$$$
\text { RMG : Rasio Murid terhadap Guru Sekolah Menengah Atas (satuan) }
$$$$
\beta_{0} \quad \text { : Intercept }
$$$$
\beta_{1}, \beta_{2}, \beta_{3}, \beta_{4} \text { : Koefisien slope variabel bebas }
$$$$
\text { e } \quad \text { : Variabel Error }
$$$$
i \quad \text { : Data cross section pada delapan Kabupaten/ Kota di Provinsi Banten }
$$$$
\boldsymbol{t} \quad \text { : Data time series waktu tahun } 2010 \mathrm{~s} / \mathrm{d} 2016
$$

$$
\mathrm{Y}_{i t}=\beta_{0}+\beta_{1} \mathrm{PP}_{i t}+\beta_{2} \mathrm{APS}_{i t}+\beta_{3} \mathrm{SKL}_{i t}+\beta_{4} R M G_{i t}+e_{i t}
$$

Identifikasi faktor-faktor internal dan eksternal yang terkait dengan peran pemerintah Provinsi Banten serta indeks pendidikan dilakukan melalui studi literatur, mempelajari gambaran umum Provinsi Banten, penyebaran kuesioner, serta hasil wawancara dengan stakeholder. Untuk perumusan strategi dilakukan dengan mengidentifikasi faktor -faktor strategis internal (kekuatan dan kelemahan) dan faktor-faktor strategis eksternal (peluang dan ancaman). Berdasarkan identifikasi tersebut dirumuskan strategi untuk memanfaatkan kekuatan dan peluang dalam meminimalisir dampak yang timbul akibat kelemahan dan ancaman yang ada (Rangkuti 1997). Strategi tersebut dapat diterapkan dalam upaya peningkatan indeks pendidikan. Selanjutnya, untuk mencapai sasaran dirumuskan programprogram yang akan dilakukan dan program tersebut dilaksanakan secara bertahap yang dituangkan dalam sebuah peta strategik.

\section{HASIL DAN PEMBAHASAN}

Kondisi Pendidikan di Provinsi Banten 
Pendidikan merupakan salah satu modal yang sangat penting bagi seseorang untuk menjalani kehidupan bermasyarakat. Melalui pendidikan seseorang dapat memperoleh berbagai macam informasi dan ilmu pengetahuan yang sangat berguna untuk dirinya dalam menjalani kehidupan. Negara yang hebat akan menempatkan pendidikan sebagai prioritas pertamanya, karena dengan pendidikan, kemiskinan pada rakyat di negara tersebut akan dapat tergantikan menjadi kesejahteraan (Meganwati 2012). Pembangunan di bidang pendidikan memerlukan peran serta yang aktif dari pemerintah dan masyarakat itu sendiri sehingga semua program peningkatan pendidikan dapat berjalan lancar dan sesuai dengan tujuan semula.

Komponen IPM yang mengukur masalah pendidikan adalah indeks pendidikan yang merupakan rataan dari Indeks Harapan Lama Sekolah dan Indeks Rata-rata Lama Sekolah. Rendahnya indeks pendidikan di Banten terutama dipengaruhi oleh rendahnya indeks harapan lama sekolah yang menduduki peringkat ke 20 di Indonesia. Sedangkan rata-rata lama sekolah di Provinsi Banten menduduki peringkat ke13 secara nasional. Nilai indeks pendidikan di Banten pada tahun 2016 adalah 0,6318. Jika kita telusuri menurut kabupaten/kota, maka terdapat 4 kabupaten di bawah rata-rata Banten. Sebaliknya, indeks pendidikan pada 4 kota lebih tinggi dibanding Banten. Hal ini secara tidak langsung membuktikan bahwa terdapat kesenjangan indeks pendidikan antara daerah kota dengan kabupaten. Daerah kota yang lebih unggul dari sisi infrastruktur dan dari sisi ekonomi cenderung memiliki indeks pendidikan yang tinggi.

Salah satu indikator kualitas pendidikan di suatu daerah adalah Angka Partisipasi Sekolah (APS). APS didefinisikan sebagai perbandingan antara jumlah murid kelompok usia sekolah tertentu yang bersekolah pada berbagai jenjang pendidikan dengan penduduk kelompok usia sekolah yang sesuai dan dinyatakan dalam persentase. Indikator ini digunakan untuk mengetahui banyaknya anak usia sekolah yang telah bersekolah di semua jenjang pendidikan. Dengan kata lain, APS menggambarkan proses partisipasi aktif penduduk usia belajar dalam proses belajar.

Secara umum, APS pada semua kelompok umur provinsi Banten tahun 2012 sampai 2016 menunjukkan tren yang meningkat dari tahun ke tahun. Angka APS SD tahun 2016 sebesar 99,43 persen, dapat diartikan juga masih ada sebesar 0,57 persen pada kelompok usia 7-12 tahun yang belum/tidak berada pada bangku Sekolah Dasar. Sedangkan APS kelompok usia 13-15 tahun (usia SMP) sebesar 95,59 persen. Sementara itu, APS kelompok usia 16-18 tahun (usia SMA) sebesar 67 persen. Semakin tinggi jenjang usia anak sekolah, semakin berkurang persentase anak yang bersekolah. Atau dengan kata lain, semakin tinggi kelompok usia anak, semakin tinggi pula anak pada kelompok usia tersebut yang meninggalkan bangku sekolah dengan berbagai penyebabnya. Kemungkinan penyebab kelompok usia 16-18 meninggalkan bangku sekolah adalah faktor ekonomi, dimana mereka lebih memilih bekerja untuk mendapatkan uang sehingga dapat membantu ekonomi keluarga daripada harus mengeluarkan uang untuk bersekolah.

Indikator lain yang berhubungan dengan pendidikan adalah rasio murid guru (RMG). RMG dapat digunakan untuk mengukur kecukupan jumlah guru untuk mendidik muridnya. Semakin tinggi rasio murid per guru akan mengakibatkan pembelajaran yang dilakukan semakin tidak efektif karena jangkauan seorang guru dalam melakukan pengawasan terhadap murid ada batasnya. Namun jika terlalu sedikit rasio murid per guru, maka akan menimbulkan masalah besarnya biaya pendidikan yang akan dikeluarkan. 
Berdasarkan Peraturan Pemerintah (PP) Nomor 74 Tahun 2008 tentang Guru, jika kita padukan dengan data Dinas Pendidikan Provinsi Banten maka rasio murid per guru di Banten memenuhi batas ideal pada tingkat SD, SMK dan MI. Sedangkan pada jenjang pendidikan yang lain, yakni SMP, SMA, MTs, dan MA rasio tersebut masih terlalu sedikit yang akan menimbulkan masalah besarnya biaya pendidikan yang akan dikeluarkan baik oleh pemerintah maupun orang tua murid itu sendiri.

Ukuran yang dapat digunakan untuk menggambarkan daya tampung sekolah adalah rasio ruang kelas dengan jumlah murid pada masing-masing tingkatan. Rasio ini digunakan sebagai acuan untuk melihat kecukupan ruang kelas dalam menampung para murid. Penambahan ruang kelas atau penambahan sekolah yang baru dapat dilakukan jika siswa yang ada melebihi batas daya tampung ruang kelas yang ada. Namun jika sebaliknya, jumlah murid terlalu sedikit, dapat dilakukan penggabungan kelas ataupun penggabungan sekolah untuk alasan efisiensi. Berdasarkan data Dinas Pendidikan Provinsi Banten, rasio murid per kelas SD/MI, SMP/MTs, SMA/MA dan SMK tahun 2015 dan 2016 menunjukkan angka yang relative besar, melebihi jumlah yang diatur dalam peraturan pemerintah di atas. Hal ini menunjukkan bahwa telah terjadi ketidakseselarasan antara jumlah murid dibandingkan dengan jumlah kelas yang tersedia sehingga pemerintah perlu membangun ruang kelas baru agar murid dapat menjalani proses belajar di kelas secara lebih kondusif.

Dalam penghitungan IPM, indeks pendidikan dibangun dari RLS dan HLS. RLS adalah rata-rata jumlah tahun yang dihabiskan oleh penduduk untuk menempuh semua jenis pendidikan formal. Lamanya sekolah (years of 64 schooling) adalah sebuah angka yang menunjukkan lamanya bersekolah seseorang dari masuk sekolah dasar sampai tingkat pendidikan terakhir. Angka rata-rata lama sekolah (mean years school) merupakan kombinasi antara partisipasi sekolah, jenjang pendidikan yang dijalani, kelas yang diduduki dan pendidikan yang ditamatkan. Rata-rata lama sekolah penduduk usia 15 tahun ke atas di Banten menunjukkan peningkatan dari tahun ke tahun yaitu dari 8,06 pada 2012 menjadi 8,37 pada tahun 2016 atau setara dengan jenjang pendidikan SMP kelas 2. Ratarata lama sekolah di Banten tahun 2016 menempati urutan 13 dari 34 provinsi di Indonesia. Jika dibandingkan dengan provinsi di Jawa, posisi Banten menempati urutan ke tiga setelah DKI Jakarta dan DI Yogyakarta.

Sedangkan harapan lama sekolah adalah sebuah angka yang menunjukkan lamanya bersekolah yang diharapkan seseorang dari masuk sekolah dasar sampai dengan tingkat pendidikan terakhir yang diduduki. Harapan lama sekolah merupakan ukuran yang dapat digunakan untuk mengetahui kondisi pembangunan sistem pendidikan di suatu wilayah. HLS didefinisikan sebagai lamanya sekolah (dalam tahun) yang diharapkan akan dirasakan oleh anak pada umur 7 tahun di masa mendatang. Meskipun RLS Banten pada 2016 menduduki peringkat ke-13 se-Indonesia, namun HLS hanya menduduki peringkat ke-20 dengan nilai 12,70 atau setara dengan kuliah tingkat 3 (tidak sampai selesai). Lebih lanjut, jika dilihat berdasarkan kabupaten/kota, pada Kabupaten Lebak, Tangerang, Serang, dan Kota Serang terlihat rendahnya pencapaian HLS atau di bawah HLS Banten

Indikator lain sebagai tolak ukur keberhasilan pendidikan yaitu Angka Melek Huruf (AMH), yaitu ukuran yang menunjukkan kemampuan penduduk suatu wilayah untuk berkomunikasi secara lisan dan tertulis serta untuk menyerap informasi dari berbagai media. Dengan demikian, AMH mencerminkan potensi perkembangan intelektual 
sekaligus kontribusi penduduk terhadap pembangunan daerah. AMH digunakan untuk mengukur keberhasilan programprogram pemberantasan buta huruf, terutama di daerah pedesaan dimana jumlah penduduk yang tidak pernah bersekolah atau tidak tamat SD masih cukup tinggi. Tingginya tingkat melek huruf menunjukkan adanya sebuah system pendidikan dasar yang efektif atau program keaksaraan yang memungkinkan sebagian besar penduduk untuk memperoleh kemampuan menggunakan kata-kata tertulis dalam kehidupan seharihari. Faktor melek huruf atau bebas buta huruf menjadi modal utama bagi penduduk untuk melanjutkan pendidikan atau belajar hal-hal lain yang lebih tinggi tingkatannya. Jika disandingkan dengan AMH Indonesia, pada 2012 - 2016 AMH
Banten masih selalu di atas AMH Indonesia. Sedangkan rendahnya AMH pada beberapa kabupaten/kota di Banten terutama disebabkan oleh kurangnya kesadaran tentang arti pentingnya pendidikan formal. Peran pemerintah dalam meningkatkan angka melek huruf dapat disertakan juga usaha dalam memberikan pemahaman kepada masyarakat tentang pentingnya pendidikan.

Faktor-Faktor yang

\section{Mempengaruhi Indeks Pendidikan Provinsi Banten}

Model data panel yang terbaik (berdasarkan Uji Chow dan Uji Hausmann) adalah Fixed Effect Model (FEM). Koefisien penduga model dapat dilihat dari Tabel 2.

Tabel 2. Hasil Analisis Regresi Data Panel dengan Pendekatan FEM

\begin{tabular}{ccccc}
\hline \hline Variable & \multicolumn{2}{c}{ Coefficient Std. Error } & t-Statistic & Prob. \\
\hline \hline PP & 0.000857 & 0.000168 & 5.106847 & 0.0000 \\
APS & 0.001472 & 0.000376 & 3.913354 & 0.0003 \\
RMG & 0.000496 & 0.000306 & 1.621448 & 0.1121 \\
SKL & 0.000320 & 0.000097 & 3.211353 & 0.0025 \\
C & 0.420382 & 0.015578 & 26.98516 & 0.0000 \\
\hline \hline \multicolumn{5}{c}{ Effects Specification } \\
\hline \hline R-squared & 0.981426 & F-statistic & 211.3560 \\
S.E. of regression & 0.011596 & Prob(F-statistic) & 0.000000 \\
\hline \hline
\end{tabular}

Sumber: Data survei diolah (2017)

Analisis regresi berganda data panel terhadap faktor-faktor yang mempengaruhi indeks pendidikan di Banten menghasilkan nilai koefisien determinasi atau R-square sebesar 0.981426 , berarti keragaman variabel dependen dapat dijelaskan oleh keragaman variabel-variabel independen dalam model sebesar 98,14 persen, sedangkan sisanya sebesar 1,76 persen dijelaskan oleh variabel lainnya di luar model. Nilai F hitung sebesar 211,35 (pvalue $=0.000)$ signifikan pada taraf $15 \%$ berarti bahwa variabel-variabel secara bersama-sama berpengaruh secara signifikan terhadap variabel indeks pendidikan. Indikator nilai $\mathrm{F}$ hitung tersebut menunjukkan bahwa model yang digunakan cukup baik dan layak digunakan. Konstanta sebesar 0,4204 menunjukkan bahwa jika tidak terdapat kenaikan atau penurunan dari nilai variabel-variabel independen maka nilai indeks pendidikan berada pada angka 0,4204 .

Hasil estimasi faktor-faktor yang mempengaruhi indeks pendidikan di Banten menunjukkan bahwa variabelvariabel independen yang berpengaruh secara signifikan dan positif adalah variabel pendapatan per kapita (PP), angka partisipasi sekolah tingkat SMA 
(APS), rasio murid per guru tingkat SMA(RMG), dan jumlah sekolah tingkat SMA (SKL). Sehingga model regresi untuk indeks pendidikan di Provinsi Banten adalah :

$$
\begin{gathered}
I P=0,0009 P P+0,0015 A P S+0,0005 R M G \\
+0,0003 S K L+0,4204
\end{gathered}
$$

Berdasarkan hasil estimasi model, dapat diartikan bahwa variabel pendapatan per kapita memiliki pengaruh positif dan signifikan terhadap indeks pendidikan. Variabel pendapatan per kapita dengan koefisien sebesar 0,0009, artinya setiap kenaikan 1 juta rupiah pendapatan per kapita akan menaikkan indeks pendidikan sebesar 0,0009 satuan, dengan asumsi variabel-variabel lainnya tetap. Pendapatan per kapita sebagai cerminan dari daya beli masyarakat. Semakin besar pendapatan per kapita maka pengeluaran masyarakat akan meningkat, termasuk pengeluaran untuk bidang pendidikan. Hasil analisis pengaruh pendapatan per kapita terhadap indeks pendidikan ini sejalan dengan hasil kajian Mahendra (2016), Sofilda et al. (2015), Melliana dan Zain (2013), Wijayanto et al. (2015). Masyarakat yang memiliki pendapatan per kapita kecil akan lebih mengutamakan pengeluaran untuk memenuhi kebutuhan primer sehingga mengabaikan kebutuhan akan pendidikan. Kondisi ini mengakibatkan kualitas indeks pendidikan di masyarakat menjadi rendah. Sebaliknya, masyarakat yang pendapatan per kapitanya besar dan kebutuhan primernya tercukupi maka akan berfikir untuk melakukan investasi di bidang pendidikan.

Variabel angka partisipasi sekolah tingkat SMA mempunyai koefisien sebesar 0,0015 yang artinya setiap kenaikan 1 persen angka partisipasi sekolah tingkat SMA akan menaikkan indeks pendidikan sebesar 0,0015 satuan, dengan asumsi variabel-variabel lainnya tetap. Berdasarkan data BPS Provinsi Banten dalam lima tahun terakhir terjadi peningkatan APS tingkat SMA dari 59,8 pada 2012 menjadi 67,00 pada 2016. Artinya pada tahun 2016 terdapat sekitar 67 persen dari penduduk usia 16-18 tahun yang sedang berada di sekolah dan menjalani proses pendidikan. Sedangkan sisanya 33 persen penduduk usia SMA tidak berada di bangku sekolah. Hal ini mungkin terjadi karena mereka harus bekerja atau tidak memiliki biaya untuk melanjutkan sekolah ke jenjang SMA. Jika mereka tidak bersekolah di jenjang SMA dan memilih untuk bekerja, artinya mereka bekerja dengan memanfaatkan ijazah maksimal SMP. Upaya peningkatan angka partisipasi sekolah tingkat SMA mutlak diperlukan agar kualitas sumber daya manusia di Banten dapat bersaing dengan daerah lainnya. Penelitian Hasbullah et al. (2012) serta Melliana dan Zain (2013) juga menghasilkan kesimpulan bahwa untuk meningkatkan Indeks Pembangunan Manusia dapat dilakukan dengan menaikkan angka partisipasi sekolah (APS). Pendidikan mutlak diperlukan karena mustahil penguasaan teknologi dan informatika dapat dilakukan pemerintah daerah di Banten. Untuk meningkatkan angka partisipasi sekolah tingkat SMA bisa diterapkan melalui wajib belajar 12 tahun, beasiswa siswa kurang mampu, subsidi silang antara masyarakat mampu dan kurang mampu dalam membayar biaya sekolah tingkat SMA, atau dengan gerakan sosial orang tua asuh dari orang mampu membiayai siswa yang kurang mampu.

Variabel rasio murid per guru tingkat SMA mempunyai nilai koefisien regresi sebesar 0,0005 yang artinya setiap kenaikan 1 satuan rasio murid per guru tingkat SMA akan menaikkan indeks pendidikan sebesar 0,0005 satuan dengan asumsi variabel-variabel lainnya tetap. Faktor kecukupan jumlah guru menjadi salah satu faktor yang diduga mempengaruhi indeks pendidikan. Namun demikian, kondisi RMG di Banten terutama pada tingkat SMA dan MA menunjukkan bahwa rasio murid guru relatif rendah, di bawah angka yang 
ideal. Hal ini tentu saja akan membuat proses pendidikan kurang efektif karena akan menimbulkan masalah dari sisi biaya yakni membuat biaya pendidikan yang akan dikeluarkan menjadi lebih besar. Pemerintah daerah Provinsi Banten harus menjaga kecukupan jumlah guru dibandingkan dengan jumlah murid yang diterima untuk meningkatkan indeks pendidikan.

Variabel jumlah bangunan SMA memiliki koefisien regresi sebesar 0,0003, artinya setiap kenaikan jumlah SMA sebesar satu unit mampu meningkatkan indeks pendidikan sebesar 0,0003 satuan dengan asumsi variabelvariabel lainnya tetap. Sebagaimana kita ketahui bahwa tidak semua layanan pendidikan di tingkat SMA sudah bebas biaya. Sulitnya akses menuju ke sekolah terutama pada daerah pelosok akan membuat penduduk berpikir ulang untuk melanjutkan sekolah. Hal ini karena benturan faktor biaya, dimana untuk menuju ke sekolah dibutuhkan biaya transportasi yang tidak sedikit. Lokasi sekolah yang terjangkau oleh penduduk dirasa akan mampu menghemat biaya yang dikeluarkan penduduk terutama dari segi transportasi. Untuk itu pemerintah perlu menambah bangunan SMA yang mudah diakses oleh penduduk terutama di daerah pelosok sehingga pada akhirnya dapat menaikkan angka indeks pendidikan di Provinsi Banten.

\section{Strategi Peningkatan Indeks Pendidikan Provinsi Banten}

Identifikasi faktor-faktor internal dan eksternal yang terkait dengan peran pemerintah Provinsi Banten serta indeks pendidikan dilakukan melalui studi literatur, mempelajari gambaran umum Provinsi Banten, penyebaran kuesioner, serta hasil wawancara dengan stakeholder. Hasil identifikasi tersebut kemudian dianalisis secara lebih lanjut untuk menentukan faktor yang menjadi kekuatan, kelemahan, peluang, maupun tantangan. Analisis tersebut dilakukan dengan menggunakan penilaian yang diberikan oleh para ahli (expert) melalui kuesioner yang telah disebarkan, kemudian setiap faktor dihitung rataratanya. Stakeholder utama dalam penelitian ini adalah Pemerintah Provinsi Banten. Penentuan strategi menggunakan pendekatan analisis SWOT. Faktor internal dan eksternal dalam analisis SWOT ditentukan dengan menggunakan penilaian dari para ahli (expert). Hasil analisis SWOT berdasarkan faktor internal (IFAS) dan faktor eksternal (EFAS) dapat dilihat pada Tabel 3.

Tabel 3. Alternatif strategi peningkatan indeks pendidikan Provinsi Banten (Matriks SWOT) Pemerintah Provinsi Banten

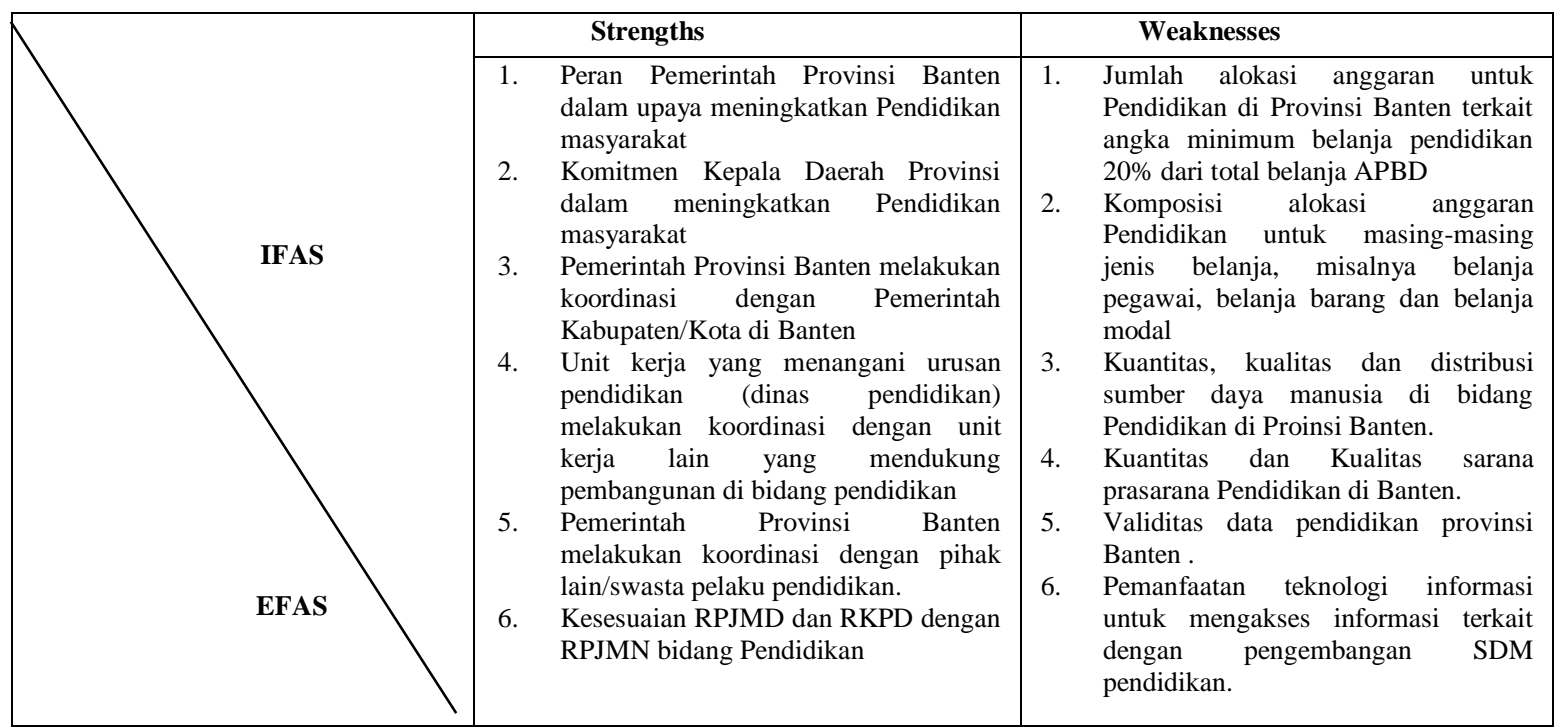




\begin{tabular}{|c|c|c|}
\hline Opportunities & STRATEGI SO & STRATEGI WO \\
\hline 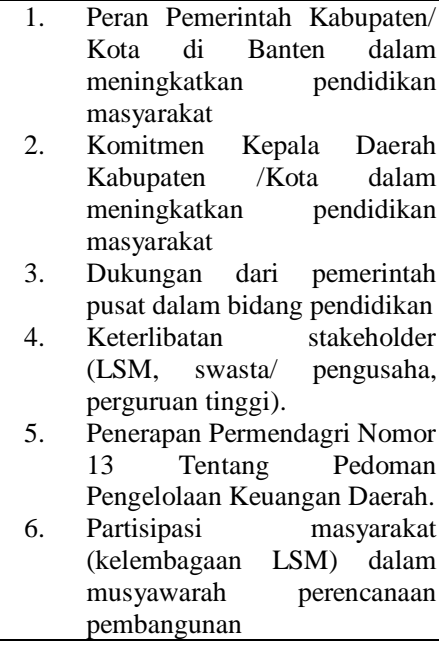 & $\begin{array}{l}\text { 1. Peningkataan strategi, kerjasama dan } \\
\text { hubungan kelembagaan antara } \\
\text { pemerintah pusat, pemerintah provinsi } \\
\text { dan pemerintah kabupaten/kota serta } \\
\text { kemitraan dengan pihak swasta (S1, } \\
\text { S2, S3, S4, S5, S6, O1, O2, O3, O4, } \\
\text { O5,O6) }\end{array}$ & $\begin{array}{l}\text { 1. Penyempurnaan kebijakan dan } \\
\text { peningkatan alokasi anggaran di } \\
\text { bidang pendidikan (W1, W2, W3, } \\
\text { W4, W5 O1, O2, O3, O4, O5, O6) }\end{array}$ \\
\hline Threats & STRATEGI ST & STRATEGI WT \\
\hline 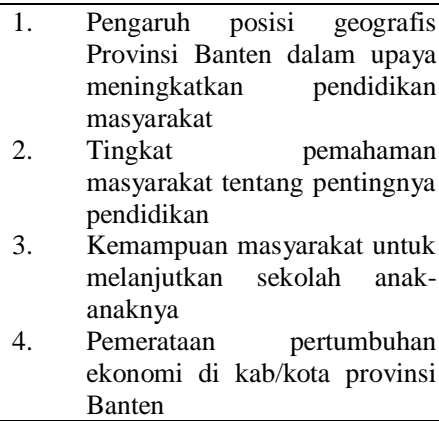 & 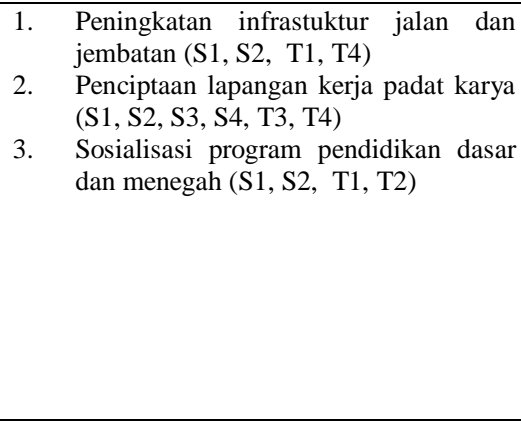 & $\begin{array}{l}\text { 1. Pembangunan data center dan jaringan } \\
\text { TIK (internet) ke Desa-Desa (W5, } \\
\text { W6, T1, T2) }\end{array}$ \\
\hline
\end{tabular}

Berdasarkan hasil pengolahan data matriks SWOT, diperoleh 6 (enam) strategi. Strategi tersebut disebarkan ke beberapa orang expert terkait, untuk memperoleh strategi prioritas. Para ahli tersebut diminta untuk membandingkan 6 grand strategi untuk diperingkatkan.dalam penetapan strategi yang benar-benar layak dan bisa diimplementasikan. Hasil data yang diperoleh diolah dengan menggunakan analisis Quantitative Strategic Planning
Matrix (QSPM). Matrik QSPM diyakini merupakan analisis yang dapat merumuskan strategi paling prioritas berdasarkan alternatif-alternatif strategi lainya. Berdasarkan hasil perhitungan matrik QSPM di atas maka dapat disimpulkan jumlah nilai tertinggi atas TAS jatuh pada strategi Penyempurnaan kebijakan dan peningkatan alokasi anggaran di bidang pendidikan dengan nilai 6.155. Strategi lainnya dapat dilihat pada tabel 4 .

Tabel 4. Hasil penilaian TAS atas matriks perencanaan strategis kuantitatif

\begin{tabular}{clc}
\hline No & \multicolumn{1}{c}{ Strategi } & TAS \\
\hline 1 & $\begin{array}{l}\text { Penyempurnaan kebijakan dan peningkatan alokasi anggaran di } \\
\text { bidang pendidikan }\end{array}$ & 6.155 \\
2 & $\begin{array}{l}\text { Peningkataan strategi, kerjasama dan hubungan kelembagaan } \\
\text { antara pemerintah pusat, pemerintah provinsi dan pemerintah }\end{array}$ & 5.964 \\
& $\begin{array}{l}\text { kabupaten/kota serta kemitraan dengan pihak swasta } \\
3\end{array}$ & 5.491 \\
4 & Sosialisasi program pendidikan dasar dan menegah & 5.103 \\
5 & Peningkatan infrastuktur jalan dan jembatan & 4.960 \\
6 & Pembangunangan kerja padat karya & 4.713 \\
\hline
\end{tabular}


Sebagai tindak lanjut dari hasil strategi utama yang sudah diperoleh dari analisis QSPM adalah melaksanakan strategi prioritas tersebut, untuk itu sangat perlu disusun rumusan strategi ke dalam bentuk pelaksanaan kebijakan operasional dalam bentuk pedoman atau acuan pelaksanaan strategi. Kebijakan operasional tersebut mempunyai posisi sebagai acuan untuk memberikan arahan pada program dan kegiatan yang akan dilakukan dengan sumberdaya yang ada. Kebijakan tersebut dilaksanakan untuk mencapai sasaran kinerja yang telah ditetapkan (Tabel 5).

Tabel 5. Perancangan strategi, program dan kegiatan

\begin{tabular}{|c|c|c|}
\hline Strategi & Program & Kegiatan \\
\hline $\begin{array}{l}\text { Penyempurnaan } \\
\text { kebijakan dan } \\
\text { peningkatan alokasi } \\
\text { anggaran di bidang } \\
\text { pendidikan }\end{array}$ & $\begin{array}{l}\text { Peningkatan kualitas } \\
\text { pendidikan di Provinsi } \\
\text { Banten }\end{array}$ & $\begin{array}{l}\text { 1. Peningkatan alokasi belanja pendidikan } \\
\text { dalam APBD secara proporsional dan } \\
\text { bertanggung jawab. } \\
\text { 2. Pembangunan dan revitalisasi sarana } \\
\text { dan prasarana pendidikan. } \\
\text { 3. Peningkatan dan pemerataan Kuantitas, } \\
\text { kualitas dan distribusi sumber daya } \\
\text { manusia di bidang. Pendidikan } \\
\text { 4. Subsidi biaya pendidikan dasar dan } \\
\text { menegah. }\end{array}$ \\
\hline
\end{tabular}

\section{KESIMPULAN}

Berdasarkan hasil dan pembahasan yang telah diuraikan dapat diambil kesimpulan sebagai berikut:

1. Indeks Pendidikan Provinsi Banten selalu meningkat dari tahun ke tahun, meskipun terdapat beberapa indikator pendidikan lainnya yang masih belum ideal.

2. Faktor-faktor yang mempengaruhi indeks pendidikan di Banten yaitu pendapatan perkapita penduduk, APS tingkat SMA, RMG tingkat SMA dan Jumlah SMA.

3. Strategi untuk meningkatkan indeks pendidikan di Provinsi Banten di antaranya: 1) Peningkatan strategi, kerjasama dan hubungan kelembagaan antara pemerintah pusat, pemerintah provinsi dan pemerintah Kabupaten/kota serta kemitraan dengan pihak swasta.; 2) Penyempurnaan kebijakan dan peningkatan alokasi anggaran di bidang pendidikan; 3) Peningkatan infrastuktur jalan dan jembatan; 4) Penciptaan lapangan kerja padat karya 5) Sosialisasi program pendidikan dasar dan menengah; dan 6) Pembangunan data center dan jaringan TIK (internet) ke desa-desa.

4. Strategi prioritas untuk meningkatkan Indeks Pendidikan di Provinsi Banten adalah melalui penyempurnaan kebijakan dan peningkatan alokasi anggaran di bidang pendidikan di antaranya dengan cara: peningkatan alokasi belanja pendidikan dalam APBD secara proporsional dan bertanggung jawab; pembangunan dan revitalisasi sarana dan prasarana pendidikan; peningkatan dan pemerataan kuantitas, kualitas dan distribusi sumber daya manusia di bidang. pendidikan; serta pemberian subsidi biaya pendidikan dasar dan menegah.

\section{DAFTAR PUSTAKA}

Ariefianto MD. 2012. Ekonometrika Esensi dan Aplikasi Menggunakan EVIEWS. Jakarta(ID): Erlangga.

[BPS] Badan Pusat Statistik. 2017. Indeks Pembangunan Manusia 2016. Jakarta(ID): Badan Pusat Statistik. 
[BPS] Badan Pusat Statistik. 2016a. Indeks Pembangunan Manusia Provinsi banten 2015. Banten(ID): Badan Pusat Statistik.

[BPS] Badan Pusat Statistik. 2016b. Potret Pendididkan Indonesia Statistik Pendidikan 2016. Jakarta(ID): Badan Pusat Statistik.

Hasbullah Y, Fauzi M, Fatimah S, Yuniarti T, Syaifudin. 2012. Analisis ArahKebijakan Ekonomi terhadap Sektor Pendidikan dalam Peningkatan IPM. Journal of Economics and Policy. Published September 2012.

Mahendra, R. 2016. Strategi Peningkatan Indeks Pendidikan Melalui Alokasi Belanja Pemerintah Daerah Bidang Pendidikan di Provinsi Jawa Timur (Tesis). Bogor(ID): Institut Pertanian Bogor.

Megawanti P. 2012. Meretas Permasalahan Pendidikan di Indonesia. Jurnal Formatif Ilmiah Pendidikan MIPA Vol. 2 No. 3.

Melliana A, Zain I. 2013. Analisis Statistika Faktor yang Mempengaruhi Indeks Pembangunan Manusia di Kabupaten/Kota Provinsi Jawa Timur dengan Menggunankan Regresi Panel. Jurnal Sains dan Seni POMITS Vol. (2); No.2.

Rangkuti F. 1997. "Analisis SWOT Teknik Membedah Kasus Bisnis". Jakarta(ID). PT. Gramedia Pustaka Utama.
Sofilda E, Nurhayati, Hamzah M.Z. 2015. Government Spending Contributions onper Capita Income and its Effect toward the Human Development Index (Comparative Study between Western Indonesia and Central \& East Indonesia). Journal of Social and Development Sciences Vol.(6); No.3.

Wijayanto A, Khusaini M, Syafitri W. 2015. Analisis Pengaruh Pengeluaran Kesehatan dan Pendidikan serta PDRB per Kapita terhadap Indeks Pembangunan Manusia (Studi terhadap Kabupaten/Kota di Jawa Timur). International Journal of Social and Local Economic Governance (IJLEG) Vol.(1);No.2.

[PP No.74/2008] Peraturan Pemerintah Nomor 74 Tahun 2008 tentang Guru.

[UU No.20/2003] Undang-Undang Nomor 20 Tahun 2003 tentang Sistem Pendidikan Nasional.

[UU No.23/2014] Undang-Undang Nomor 23 Tahun 2014 tentang Pemerintahan Daerah. 